\title{
LESIONS PRODUCE BY CLOSTRIDIUM BUTYRICUM STRAIN CB 1002 IN LIGATED INTESTINAL LOOPS IN GUINEA PIGS
}

\author{
M. R. POPOFF AND P. RavisSE* \\ Unité des Anaérobies and ${ }^{*}$ Unité d'Histopathologie, Institut Pasteur, 25, rue du \\ Docteur Roux, 75724 Paris Cedex 15, France
}

\begin{abstract}
SummaRY. Heated spores $\left(80^{\circ} \mathrm{C}, 10 \mathrm{~min}\right)$ of Clostridium butyricum strain CB 1002 isolated from a fatal case of necrotising enterocolitis in a human neonate were inoculated into ligated intestinal loops prepared in young conventional guinea pigs. Necropsy findings $18 \mathrm{~h}$ later included congestion, patchy haemorrhage of the intestinal mucosa and bacteraemia. No abnormalities were observed in control loops given inocula of inactivated spores (heated at $100^{\circ} \mathrm{C}$ for $10 \mathrm{~min}$ ) or TYG 6 medium. The results suggest that vascular lesions are produced by $C$. butyricum in the intestine of young conventional guinea pigs.
\end{abstract}

\section{INTRODUCTION}

Bacterial proliferation in the intestinal tract is associated with the pathogenesis of neonatal necrotising enterocolitis (NNE) in infants (Brown and Sweet, 1982). Clostridia are frequently isolated from the faeces of these patients (Kosloske et al., 1978; Kliegman, 1979; Kosloske and Ulrich, 1980), and Clostridium butyricum has been identified in several outbreaks of NNE (Howard et al., 1977; Laverdière et al., 1978; Smith et al., 1980; Sturm et al., 1980; Popoff and Sebald, 1981). To investigate the pathogenicity of $C$. butyricum we examined its effects in ligated intestinal loops in guinea pigs.

\section{MATERIAL AND METHODS}

Bacterial strain and growth medium. C. butyricum strain CB 1002 (Magot et al., 1983) was isolated from stools of a neonate aged 3 weeks that died of NNE (Popoff and Sebald, 1981).

Two growth media were used: TYG contained trypticase (Difco, Paris, France) 3\%, yeast extract (Difco) $2 \%$, and glucose $0.5 \%$; TYG 6 contained glucose $6 \%$. Spore stocks were prepared on D medium (Labbe, 1981) incubated anaerobically for $24 \mathrm{~h}$ at $37^{\circ} \mathrm{C}$ and stored at $4^{\circ} \mathrm{C}$.

Surgical and experimental procedures. The ligated intestinal loop technique (LILT) described previously in rabbits (Duncan et al., 1968), was used. Young male Hartley conventional guinea pigs, weighing 100-150 g, were starved for $24 \mathrm{~h}$ and anaesthetised by intramuscular injection of ketamine (Imalgene 500, Institut Merieux, Lyon, France; $200 \mathrm{mg} / \mathrm{kg}$ ). The abdomen was shaved and an incision was made in the midline; one 10-cm loop was prepared in the ileum with no. 4-0 silk (Moria-Dugast, Paris, France) $20 \mathrm{~cm}$ proximal to the caecum of each guinea pig. Spore suspensions were heated at $80^{\circ} \mathrm{C}$ for $10 \mathrm{~min}$, diluted in $2 \mathrm{ml}$ of freshly prepared TYG 6 and injected through a $30 \mathrm{G} \frac{1}{2}$-in needle into the lumen of the loop. TYG 6 alone or spores inactivated 
by heating at $100^{\circ} \mathrm{C}$ for $10 \mathrm{~min}$ were inoculated into control loops. The abdomen was closed with no. 4-0 silk. The animals were killed $18 \mathrm{~h}$ later and a necropsy was performed immediately.

Bacterial examination. Immediately after death, $0.5 \mathrm{ml}$ of heart blood was removed into $7 \mathrm{ml}$ of TYG medium and incubated in anaerobic conditions at $37^{\circ} \mathrm{C}$. The bacteria were identified after $24 \mathrm{~h}$ by the methods of Brefort and Sebald (1977).

A selective medium was used to count $C$. butyricum in the contents of loops; it consisted of

TABLE

Results of ligated-intestinal-loop experiments with C. butyricum CB1002 in guinea pigs

\begin{tabular}{|c|c|c|c|c|}
\hline $\begin{array}{l}\text { Number of } \\
\text { spores }\end{array}$ & $\begin{array}{l}\text { Treatment } \\
\text { of spores }\end{array}$ & $\begin{array}{l}\text { Number } \\
\text { of } \\
\text { animals }\end{array}$ & $\begin{array}{l}\text { Bacterial counts } \\
\text { (cfu/ml of intestinal } \\
\text { loop content) }\end{array}$ & $\begin{array}{c}\text { Severity of intestinal } \\
\text { lesions }\end{array}$ \\
\hline $\left.\begin{array}{l}\text { Bacteraemic an } \\
2 \times 10^{8} \\
2 \times 10^{8} \\
2 \times 10^{6} \\
2 \times 10^{7} \\
2 \times 10^{6}\end{array}\right\}$ & $\begin{array}{c}80^{\circ} \mathrm{C} \text { for } \\
10 \mathrm{~min}\end{array}$ & $\left\{\begin{array}{l}1 \\
1 \\
1 \\
1 \\
1\end{array}\right.$ & $\begin{array}{l}5 \times 10^{8} \\
5 \times 10^{8} \\
2 \times 10^{8} \\
9 \times 10^{7} \\
6 \times 10^{7}\end{array}$ & $\begin{array}{l}\text { acute } \\
\text { moderate } \\
\text { moderate } \\
\text { acute } \\
\text { moderate }\end{array}$ \\
\hline $\left.\begin{array}{l}\text { Non-bacteraem } \\
2 \times 10^{7} \\
2 \times 10^{8} \\
2 \times 10^{6} \\
2 \times 10^{7} \\
2 \times 10^{6} \\
2 \times 10^{8}\end{array}\right\}$ & $\begin{array}{c}80^{\circ} \mathrm{C} \text { for } \\
10 \mathrm{~min} \\
100^{\circ} \mathrm{C} \text { for }\end{array}$ & $\left\{\begin{array}{l}1 \\
1 \\
1 \\
1 \\
1 \\
5\end{array}\right.$ & $\begin{array}{l}7 \times 10^{8} \\
2 \times 10^{8} \\
2 \times 10^{8} \\
8 \times 10^{7} \\
6 \times 10^{7} \\
0\end{array}$ & $\begin{array}{l}\text { moderate } \\
\text { moderate } \\
\text { moderate } \\
\text { acute } \\
\text { moderate } \\
\ldots .\end{array}$ \\
\hline $\begin{array}{l}\text { TGY } 6 \\
\text { medium alone }\end{array}$ & $\begin{array}{l}10 \mathrm{~min} \\
\ldots\end{array}$ & 5 & 0 & $\cdots$ \\
\hline
\end{tabular}

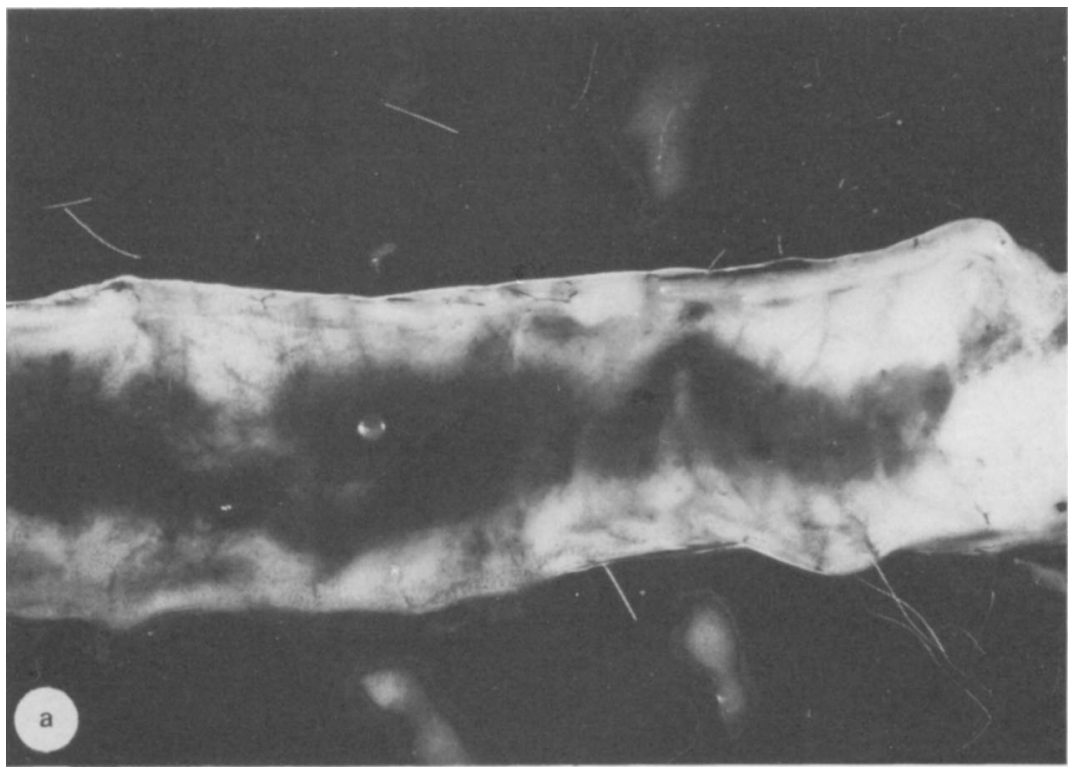

FIG. 1.-Macroscopic appearance of ligated intestinal loops: (a and b) inocula of C. butyricum CB 1002 spores, heated at $80^{\circ} \mathrm{C}$ for $10 \mathrm{~min}$; (c) inoculum of TYG 6 alone. The intestinal loops were opened longitudinally and observed by transillumination $(\times 2)$; (a) shows extensive haemorrhage and congestion of the intestinal mucosa. 

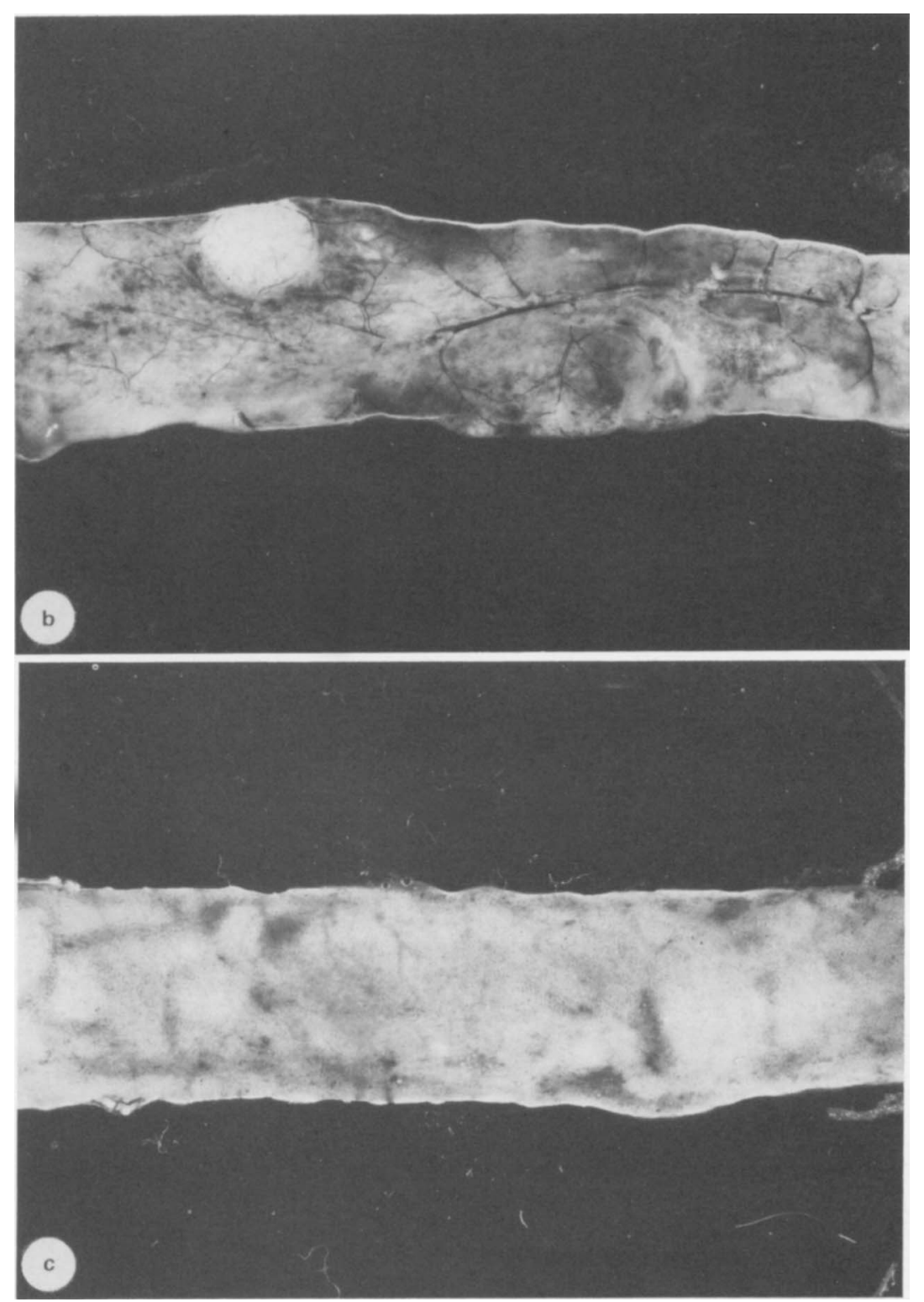

FIG. I (cont.). Macroscopic appearance of ligated intestinal loops: (b) shows patchy haemorrhage and milder congestion and (c) is a control loop.

basal medium (Cummins and Johnson, 1971), trimethoprim (Sigma, Paris, France) $16 \mu \mathrm{g} / \mathrm{ml}$, D-cycloserine (Sigma) $10 \mu \mathrm{g} / \mathrm{ml}$ and polymyxin B sulphate $20 \mu \mathrm{g} / \mathrm{ml}$. Serial ten-fold dilutions of intestinal loop contents were made in fluid basal medium, and plates were inoculated with $0.1 \mathrm{ml}$ of each dilution and incubated at $37^{\circ} \mathrm{C}$ for $48 \mathrm{~h}$. All manipulations and incubations were done in an anaerobic chamber (La Calhène, Paris, France).

Morphological and histological examinations. The loop was excised, placed in a petri dish and its length was measured. A longitudinal incision was made and the volume of the contents was measured. A sample was fixed in Bouin solution, embedded in paraffin, serially sectioned and stained with haematoxylin and eosin. After gentle washing of the loop with phosphate buffered saline $\left(\mathrm{NaCl} 0.8 \% ; \mathrm{Na}_{2} \mathrm{H} \mathrm{PO}_{4} 2.7 \% ; \mathrm{NaH}_{2} \mathrm{PO}_{4} 0.34 \% ; p \mathrm{H} 7 \cdot 2\right)$ to remove the luminal debris, the loop was spread out and the lesions compared with those in control loops. 

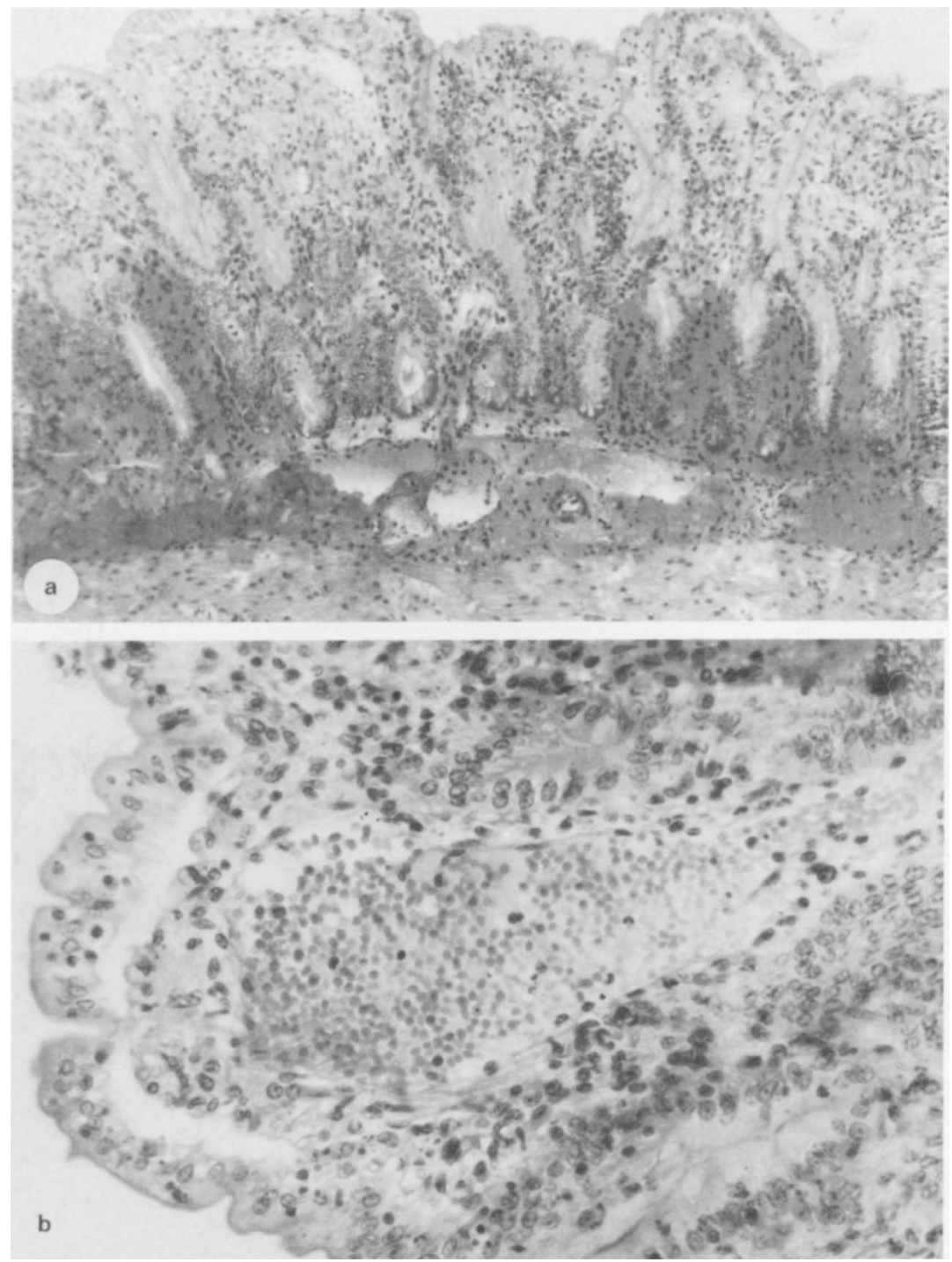

FIG. 2.-Histopathological changes in ligated intestinal loop after inoculation of C. butyricum CB 1002 spores heated at $80^{\circ} \mathrm{C}$ for 10 min (Hematoxylin and eosin): (a) shows haemorrhage in the mucosa and submucosa, and inflammatory cell infiltrate in the lamina propria $(\times 100)$; (b) shows congestion of the lamina propria $(\times 250)$.

\section{RESULTS}

\section{Morphological changes in intestinal loops}

Intestinal loops in 10 guinea pigs inoculated with spores of C. butyricum CB 1002 heated at $80^{\circ} \mathrm{C}$ for $10 \mathrm{~min}$ showed severe to moderate changes (table). In severely affected loops, haemorrhagic fluid $(0.5-0.6 \mathrm{ml} / \mathrm{cm})$ had accumulated and there was severe congestion and extensive haemorrhages of the mucosa (fig. 1a). Moderate 


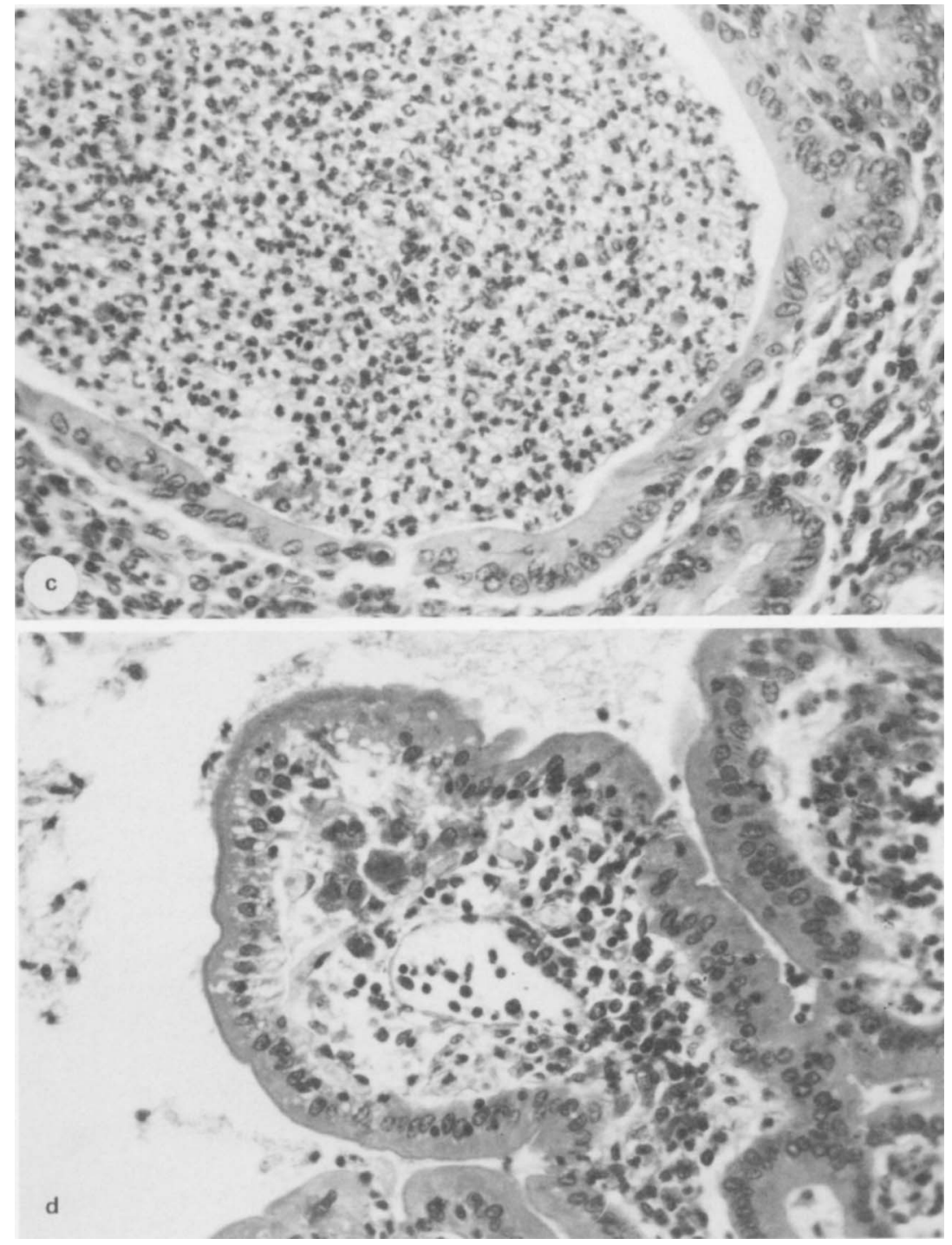

Fig. 2 (cont.). Histopathological changes in ligated intestinal loops: (c) shows microabscesses in the mucosa $(\times 250)$; and (d) shows inflammatory-cell infiltrate in the villi (lymphocytes, macrophages, histocytes and a few polymorphonuclear neutrophils $(\times 250)$.

lesions comprised a smaller accumulation of fluid $(0 \cdot 1-0 \cdot 3 \mathrm{ml} / \mathrm{cm})$, patchy haemorrhage and petechiae of the mucosa (fig. 1b). The mesenteric vessels were dilated in every case.

No obvious abnormalities were seen when spores of C. butyricum CB 1002 inactivated by heating at $100^{\circ} \mathrm{C}$ for $10 \mathrm{~min}$ or TYG 6 alone were inoculated into control loops (fig. 1c).

\section{Bacterial counts}

The counts of $C$. butyricum CB 1002 in intestinal loops are shown in the table. The organisms were also recovered from the heart blood of 5 out of 10 animals. 


\section{Histological observations}

By light microscopy, the severe intestinal lesions were characterised by congestion and small areas of haemorrhage in the mucosa; the lamina propria and submucosa were infiltrated with lymphocytes, macrophages, histiocytes and a few polymorphonuclear neutrophils, and in one case micro-abscesses were present in the mucosa. These changes are shown in figs $2 \mathrm{a}-2 \mathrm{~d}$. Lysis of epithelial cells was observed in some areas, but it was mild and the intestinal villi were not disrupted. Staining of sections by Gram's method demonstrated gram-positive rods in the intestinal lumen; small numbers were also present in the crypts, but not in the lamina propria or in the mucosa. Less severe changes were seen in the loops with moderate macroscopic changes. In the control loops, infiltration of a small number of neutrophils was present in the lamina propria and the submucosa.

\section{DISCUSSION}

The results of this study show that $C$. butyricum strain CB 1002 caused intestinal damage and bacteraemia after inoculation into ligated loops in guinea pigs. The lesions consisted of vascular alterations (congestion and patchy haemorrhages in the intestinal mucosa) and inflammatory infiltration of the intestinal wall. Necrotic lesions were absent or mild, and may have been attributable to early autolysis. Vascular modifications, haemorrhages in the mucosa and submucosa, and extensive mucosal necrosis occur in natural disease (Pedersen et al., 1976; Laverdière et al., 1978) and the vascular modifications may be an early stage of NNE (Swanson and Landing, 1980); this might be demonstrated in intestinal loops left for longer than $18 \mathrm{~h}$ which is unacceptable with this technique.

We used conventional guinea pigs in these experiments because we were unable to obtain germ-free animals. Although the intestinal bacteria may have interacted with $C$. butyricum, we did not observe significant vascular alterations in the control intestinal loops.

Little is known about the pathogenicity of $C$. butyricum. Enteritis was produced in neonatal germ-free rats after oral inoculation of C. butyricum (Lawrence et al., 1982). The pathological findings were mainly confined to the distal ileum, and ranged from loss of villi to patchy haemorrhage of the gut wall and necrosis. However, the authors failed to reproduce these results (Lawrence and Bates, 1983). Host factors may account for the different responses between the human neonate and experimental animals. Moreover, it has been shown that susceptibility to NNE is closely related to the functional maturation of the gastrointestinal tract (Wilson et al., 1982 and 1983). Such events could explain the inconsistent results of experimental infections in laboratory animals.

Our experimental model shows that $C$. butyricum strain CB 1002 can induce vascular intestinal damage, but the other lesions of NNE (extensive necrosis and pneumatosis) were not observed. Further work is in progress to develop a more suitable animal model for NNE.

We thank Professor M. Sebald for reading the manuscript and making helpful suggestions. 


\section{REFERENCES}

Brefort G, Sebald M 1977 Recherche et identification des anaérobies en bactériologie courtante. Revue du Praticien 27:248-254.

Brown E G, Sweet A Y 1982 Neonatal necrotizing enterocolitis. Pediatric Clinics of North America 29:1149-1170.

Cummins C S, Johnson J L 1971 Taxonomy of the Clostridia: wall composition and DNA homologies in Clostridium butyricum and other butyric acid-producing Clostridia. Journal of General Microbiology 67:33-46.

Duncan C L, Sugiyama H, Strong D H 1968 Rabbit ileal loop response to strains of Clostridium perfringens. Journal of Bacteriology 95:1560-1566.

Howard F M, Bradley J M, Flynn D M, Noone P, Szawatkowski M 1977 Outbreak of necrotising enterocolitis caused by Clostridium butyricum. Lancet 2:1099-1102.

Kliegman R M 1979 Neonatal necrotizing enterocolitis: implications for an infectious disease. Pediatric Clinics of North America 26:327-344.

Kosloske A M, Ulrich J A, Hoffman H 1978 Fulminant necrotising enterocolitis associated with Clostridia. Lancet 2:1014-1016.

Kosloske A M, Ulrich J A 1980 A bacteriologic basis for the clinical presentations of necrotizing enterocolitis. Journal of Pediatric Surgery 15:558-564.

Labbe R G 1981 Enterotoxin formation by Clostridium perfringens type A in a defined medium. Applied and Environmental Microbiology 41:315-317.

Laverdière M, Robert A, Chicoine R, Salet D, Rosenfeld R 1978 Clostridia in necrotising enterocolitis. Lancet 2:377.

Lawrence G, Bates J, Gaul A 1982 Pathogenesis of neonatal necrotising enterocolitis. Lancet 1:137-139.

Lawrence G W, Bates J 1983 Pathogenesis of neonatal necrotizing enterocolitis. Lancet 1:540.

Magot M, Carlier J P, Popoff M R 1983 Identification of Clostridium butyricum and Clostridium beijerinckii by gas-liquid chromatography and sugar fermentation: correlation with DNA homologies and electrophoretic patterns. Journal of General Microbiology 129:2837-2845.

Pedersen P V, Halveg A B, Hansen F H, Christiansen E D, Justesen T, Hogh P 1976 Necrotising enterocolitis of the newborn - is it gas-gangrene of the bowel? Lancet 2:715-716.

Popoff M R, Sebald M 1981 Mise en évidence chez Clostridium butyricum d'un facteur thermostable responsable du pouvoir pathogène expérimental. Comptes-Rendus de l'Académie des Sciences de Paris Serie III 292:763-766.

Smith M F, Borriello S P, Clayden G S, Casewell M W 1980 Clinical and bacteriological findings in necrotizing enterocolitis: a controlled study. Journal of Infection 2:23-31.

Sturm R, Staneck J. L, Stauffer L R, Neblet W W 1980 Neonatal necrotizing enterocolitis associated with penicillin-resistant, toxigenic Clostridium butyricum. Pediatrics 66:928-931.

Swanson V L, Landing B M 1980 Pathology. In: Brown E G, Sweet A Y (eds) Neonatal necrotizing enterocolitis. Grune and Stratton New York, p 129.

Wilson R, Kanto W P, McCarthy B J, Burton A, Lewin P, Feldman R A 1982 Age at onset of necrotizing enterocolitis: an epidemiologic analysis. Pediatric Research 16:82-84.

Wilson R, Del Portillo M, Schmidt E, Feldman R A, Kanto W P 1983 Risk factors for necrotizing enterocolitis in infants weighing more than 2,000 grams at birth: a case-control study. Pediatrics 71:19-22. 